\title{
Agrobacterium-mediated Transformation of Buddleia Species
}

\author{
Wenhao Dai ${ }^{1,4}$, Yuanjie $\mathrm{Su}^{2}$, Hongxia Wang ${ }^{2}$, and Ceilo Castillo \\ Department of Plant Sciences, North Dakota State University, Department \\ \#7670, P.O. Box 6050, Fargo, ND 58108
}

Additional index words. organogenesis, woody plant, cocultivation time

\begin{abstract}
Two Buddleia cultivars, B. davidii 'Potters Purple' and Buddleia 'Lochinch', were transformed using Agrobacterium tumefaciens strain EHA105 harboring the binary vector pBI121 carrying the neomycin phosphotransferase gene and $\beta$-glucuronidase gene (uidA). Transgenic plants were recovered from the Agrobacterium-infected leaf tissues through organogenesis in the selection medium (woody plant medium containing $250 \mathrm{mg} \cdot \mathrm{L}^{-1}$ cefotaxime plus $500 \mathrm{mg} \cdot \mathrm{L}^{-1}$ carbenicillin plus $\left.40 \mathrm{mg} \cdot \mathrm{L}^{-1} \mathrm{kanamycin}\right)$. The rate of shoot regeneration from transformed leaf tissues increased from $5.7 \%$ to $32 \%$ through extending cocultivation time from 3 to 9 days. Integration of marker genes was verified with polymerase chain reaction (PCR) and Southern blot analysis. Southern blot analysis confirmed that one to three copies of transgenes were integrated into the buddleia genome. This transformation system could be used for improvement of buddleia or other related species. Chemical names used: 6-benzyladenine (BA), naphthalene acetic acid (NAA), acetosyringone (AS), 5-Bromo-4-chloro-3-indoxyl-beta-D-glucuronide cyclohexylammonium (X-Glu), cefotaxime (Cef), carbenicillin (Carb), kanamycin (Km).
\end{abstract}

The genus Buddleia consists of more than 100 species, of which many are woody shrubs providing colorful and fragrant flowers for landscaping and gardening (Dirr, 1998; Hogan, 2003). Buddleia plants have a wide adaptability to various environmental conditions such as high soil $\mathrm{pH}$ and cold hardiness and can be grown in most states of the United States (Dirr, 1998; Hogan, 2003). Buddleia davidii, known as butterfly bush, is a perennial landscape plant that can also be used as an annual bedding plant. Butterfly bush was imported to North America from China in the early 1900 s. It is characterized as a fastgrowing deciduous shrub with a long flowering period and is well received by many gardeners. However, this species has such concerns as limited flower color (most reds and blues are muddled), excessive growth (1 to $5 \mathrm{~m}$ tall, lanky, and wide-spreading), and is a natural virus host (e.g., cucumber mosaic virus, alfalfa mosaic or tomato ringspot virus) (Podaras, 2005). Recently, invasiveness of this species has become an issue because Buddleia davidii is a prolific seed producer and its seeds can be dispersed by wind and water and may remain dormant in the soil for many years (Sheppard et al., 2006).

Received for publication 24 Nov. 2008. Accepted for publication 24 Jan. 2009.

This research was supported in part by McIntireStennis Project ND06212 and Landscape Plant Development Center.

We thank Dr. J. Ransom for SAS analysis and Drs. M. Christoffers, H. Hatterman-Valenti, and D. Herman for reviewing the manuscript.

${ }^{1}$ Assistant Professor.

${ }^{2}$ Graduate Student.

${ }^{3}$ Research Specialist.

${ }^{4}$ To whom reprint requests should be addressed; e-mailwenhao.dai.@ndsu.edu.
A colorful, compact, and sterile Buddleia davidii cultivar would be highly desirable for landscape purposes. Attempts to improve Buddleia davidii using conventional breeding methods have resulted in limited success. Different ploidy levels among species in the genus Buddleia may impede interspecific crosses; therefore, elite traits cannot be efficiently integrated into newly developed plants (Rose et al., 2000; Tobutt, 1993).

Transgenic plants have been obtained in many woody species (Petri and Burgos, 2005; Poupin and Arce-Johnson, 2005). However, transformation of Buddleia species has not been documented to date. The objective of this study was to develop a gene transformation protocol for further improvement of Buddleia species.

\section{Materials and Methods}

Plant material. Two cultivars, Buddleia davidii 'Potters Purple' and Buddleia 'Lochinch', were used in this study. In vitro cultures of the cultivars were subcultured every 4 weeks in Murashige and Skoog (MS) medium (Murashige and Skoog, 1962) supplemented with $2.67 \mu \mathrm{M}$ benzyladenine (BA), $2 \%$ sucrose, and $0.35 \%$ phytagel (Sigma Chemical Co., St. Louis, MO) and adjusted to $\mathrm{pH} 5.8$ before autoclaving. These cultures were maintained at $25^{\circ} \mathrm{C}$ under coolwhite light at $36 \mu \mathrm{mol} \cdot \mathrm{m}^{-2} \cdot \mathrm{s}^{-1}$ with a $16-\mathrm{h}$ photoperiod.

Plant transformation. An efficient shoot regeneration system of these two Buddleia cultivars was developed by Dai and Castillo (2007). Previous experiments determined that kanamycin at $40 \mathrm{mg} \cdot \mathrm{L}^{-1}$ completely inhibited shoot regeneration from leaf tissues. Therefore, a series of media used for the buddleia transformation were made based on the result of the previous experiments:
1. Shoot regeneration medium (SRM): For 'Potters Purple': woody plant medium (WPM) (Lloyd and McCown, 1980) + $0.35 \%$ phytagel $+5 \mu \mathrm{M} \mathrm{BA}+5 \mu \mathrm{M}$ indole acetic acid (IBA); for 'Lochinch': $\mathrm{WPM}+0.35 \%$ phytagel $+20 \mu \mathrm{M} \mathrm{BA}+$ $4 \mu \mathrm{M}$ IBA.

2. Cocultivation medium (CCM): SRM + $200 \mu \mathrm{M}$ acetosyringone (AS).

3. Selection medium (SLM): SRM + $\mathrm{CCK}_{40}\left[250 \mathrm{mg} \cdot \mathrm{L}^{-1}\right.$ cefotaxime (Cef) $+500 \mathrm{mg} \cdot \mathrm{L}^{-1}$ carbenicillin $(\mathrm{Carb})+40$ $\mathrm{mg} \cdot \mathrm{L}^{-1}$ kanamycin] (antibiotics were filter-sterilized and added into the autoclaved medium when the medium temperature cooled down to $\approx 50{ }^{\circ} \mathrm{C}$ ).

Agrobacterium strain EHA105 (Hood et al., 1993), carrying pBI121 (Clontech, Palo Alto, CA) containing the nptII gene encoding neomycin phosphotransferase and the uidA gene coding for $\beta$-glucuronidase (GUS) (Fig. $1)$, was grown overnight in Luria-Bertani medium with $100 \mathrm{mg} \cdot \mathrm{L}^{-1}$ kanamycin at $28{ }^{\circ} \mathrm{C}$ in a shaker at $150 \mathrm{rpm}$. Cells were collected by centrifugation at $6000 \mathrm{rpm}$ for $15 \mathrm{~min}$, resuspended to 1.0 o.d. at $\mathrm{Abs}^{600}$ in WPM medium supplemented with $20 \mu \mathrm{M}$ AS without kanamycin, and incubated at $28{ }^{\circ} \mathrm{C}$ in a shaker at $150 \mathrm{rpm}$ for $2 \mathrm{~h}$. In vitro leaves were cut through the main vein once $(\approx 0.5 \times 0.5$ $\mathrm{cm})$ and submerged in a bacterial culture solution for $30 \mathrm{~min}$ at $28{ }^{\circ} \mathrm{C}$. Leaf explants were then removed from the bacterial culture solution, blotted on sterilized paper towels, and transferred to the CCM medium in petri dishes $(100 \mathrm{~mm} \times 15 \mathrm{~mm}, 25 \mathrm{~mL}$ medium) for cocultivation in the dark at room temperature. The effect of cocultivation time on transformation efficiency was tested. After cocultivation for 3,6 , and $9 \mathrm{~d}$, leaf explants were washed twice with sterile deionized and distilled water $\left(\mathrm{ddH}_{2} \mathrm{O}\right)$ and once with sterile $\mathrm{ddH}_{2} \mathrm{O}$ plus $250 \mathrm{mg} \cdot \mathrm{L}^{-1} \mathrm{Cef}$ and $500 \mathrm{mg} \cdot \mathrm{L}^{-1}$ Carb, and then blotted with sterile paper towels. These Agrobacterium-infected leaf explants were inoculated on the SLM for selection in the dark. Cultures were subcultured in fresh SLM and moved to a culture room under the regular culture conditions previously described. Each treatment (cocultivation time) had at least three SLM plates with 10 explants per plate. The control plates were SLM without kanamycin. The experiment was repeated three times.

Shoots regenerated/recovered from SLM were proliferated in MS medium supplemented with $2.67 \mu \mathrm{M}$ BA and $\mathrm{CCK}_{40}$. Proliferated shoots (greater than $2.0 \mathrm{~cm}$ ) were rooted based on the method of Dai and Castillo (2007). Rooted plants were transferred to Sunshine Mix \#1 (Fisons Western Corp., Vancouver, Canada) and grown in the greenhouse under a 16-8-h photoperiod with the temperature adjusted to $25^{\circ} \mathrm{C}$ in the daytime and $15^{\circ} \mathrm{C}$ at night.

Histochemical $\beta$-glucuronidase assay. Leaves from the recovered plants were subjected to GUS screening as described by Jefferson (1987). In brief, in vitro young and greenhouse-grown leaves were submerged in 


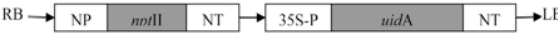

Fig. 1. Schematic representation of the T-DNA portion of pBI121 plasmid (Clontech, Palo Alto, CA). RB and LB = T-DNA right and left borders; $\mathrm{NP}=$ nopaline synthase promoter; $\mathrm{NT}=$ nopaline synthase terminator; $n p t \mathrm{II}=$ neomycin phosphotransferase gene; uidA = $\beta$-glucuronidase gene; $35 \mathrm{~S}-\mathrm{P}=\mathrm{CaMV} 35 \mathrm{~S}$ promoter from cauliflower mosaic virus. The vector was introduced into the disarmed Agrobacterium tumefaciens EHA 105.

a GUS staining solution containing $200 \mu \mathrm{L}$ $\mathrm{ddH}_{2} \mathrm{O}$ and $200 \mu \mathrm{L}$ X-Glu solution $\left(2 \mathrm{mg} \cdot \mathrm{mL}^{-1}\right.$; Gold Biotechnology, Inc., St. Louis, MO). After incubating at $37{ }^{\circ} \mathrm{C}$ overnight, stained leaves were gradually bleached with $70 \%$ to $100 \%$ ethanol. GUS staining was observed and photographed under a microscope.

Polymerase chain reactions. Genomic DNA was extracted from young leaves of putative transformed and nontransformed buddleia plants based on the method of Lodhi et al. (1994). Reactions of polymerase chain reaction (PCR) were carried out in $25 \mu \mathrm{L}$ volume containing $200 \mu \mathrm{M}$ dNTPs, $1 \mu \mathrm{M}$ of each oligonucleotide primer, 2.5 units Taq DNA Polymerase (Promega, Madison, WI), and $25 \mathrm{ng}$ DNA. The reaction conditions were: 1 cycle at $94{ }^{\circ} \mathrm{C}$ for $5 \mathrm{~min}, 40$ cycles of $94^{\circ} \mathrm{C}$ for $1 \mathrm{~min}, 60^{\circ} \mathrm{C}$ for $1 \mathrm{~min}$, and $72^{\circ} \mathrm{C}$ for $30 \mathrm{~s}$ and then one cycle at $72{ }^{\circ} \mathrm{C}$ for $7 \mathrm{~min}$. Amplified DNA fragments $(10 \mu \mathrm{L}$ of reaction) were electrophoresed on a $1 \%$ agarose gel, stained with ethidium bromide, and visualized under ultraviolet light. The primers used for screening transgenes were: $n p t I I$ reverse: 5'-GCAGGCATCGCCATGGGTC ACGACGA-3' and $n p t$ II forward: $5^{\prime}$-GCCCT GAATGAACTGCAGGACGAGGC-3'; and uidA reverse: 5'-CCCGGCAATAACATA CGGCGTG-3' and uidA forward: 5' -CCT GTAGAAACCCCAACCCGTG-3'; which produced 410-bp and 365-bp products, respectively.

Southern blot analysis. Approximately 25 to $35 \mu \mathrm{g}$ of genomic DNA was digested in a $50 \mu \mathrm{L}$ reaction with $1 \mu \mathrm{L}$ HindIII restriction enzyme at $37^{\circ} \mathrm{C}$ for $2.5 \mathrm{~h}$, electrophoresed on a $0.8 \%$ TAE (Tris-acetate ethylenediamine tetra-acetic acid) agarose gel, and blotted to a positively charged Hybond-N+ nylon membrane (Amersham Pharmacia Biotech, Little Chalfont Buckinghamshire, U.K.). Similarly, digested DNA from untransformed buddleia plants was used as a negative control, whereas 25 to $40 \mathrm{ng}$ of pBI121 plasmid DNA was used as a positive control. The blot was probed with randomly primed ${ }^{32} \mathrm{P}$-labeled $n p t I I$ PCR product $\left(4 \mu \mathrm{L} \mathrm{ddH}_{2} \mathrm{O}, 1 \mu \mathrm{L}\right.$ 6-mer oligo primers, $1.5 \mu \mathrm{L} 5 \mathrm{~mm}$ dNTPs, $1.5 \mu \mathrm{L} 10 \times$ Klenow buffer, $1 \mu \mathrm{L}$ Klenow polymerase, and $5 \mu \mathrm{L} \mathrm{dCTP}{ }^{32} \mathrm{P}$ ). Prehybridization was at $65{ }^{\circ} \mathrm{C}$ for $6 \mathrm{~h}$ in the hybridization solution $[1 \%$ bovine serum albumin Fraction $\mathrm{V}$ (Sigma Chemical Co.), $0.5 \mathrm{M} \mathrm{NaH} \mathrm{NO}_{4}$ ( $\mathrm{pH} 7.0$ ), 7\% sodium dodecyl sulfate (SDS), $1 \mathrm{~mm}$ ethylenediamine tetra-acetic acid]. The denatured DNA probe was added directly to the blot in the prehybridization mixture, hybridized at $65^{\circ} \mathrm{C}$ for $16 \mathrm{~h}$, and then washed with $2 \times$ SSC $(200 \mu \mathrm{M}$ sodium chloride and $200 \mu \mathrm{M}$ sodium citrate) for $35 \mathrm{~min}$ followed with $0.5 \times \mathrm{SSC}+0.1 \% \mathrm{SDS}$, and $0.1 \times$ $\mathrm{SSC}+0.1 \% \mathrm{SDS}$ for $10 \mathrm{~min}$ each at $65{ }^{\circ} \mathrm{C}$ on a shaker. The blot was exposed to $\mathrm{X}$-ray film (Kodak, New York, NY) at $-80{ }^{\circ} \mathrm{C}$ for $72 \mathrm{~h}$ and developed per the manufacturer's instructions.

Statistical analysis. Data from all experiments were subject to analysis of variation and mean comparison using the GLM procedure of SAS software Version 9.1 (SAS Institute, 2004)

\section{Results and Discussion}

Effect of cocultivation time on shoot recovery. In vitro shoots were regenerated from leaf explants infected with Agrobacterium EHA105 carrying pBI121 after 8 weeks' culture (two subcultures) in the selection medium (Table 1; Fig. 2A). No shoot was regenerated from noninfected leaf explants. Cocultivation time significantly affected regeneration rate. An average of $32 \%$ of leaf explants produced shoots from SLM medium containing $40 \mathrm{mg} \cdot \mathrm{L}^{-1}$ kanamycin after $9 \mathrm{~d}$ cocultivation, whereas only $5.7 \%$ and $10.6 \%$ of explants developed shoots after 3 and 6 d cocultivation, respectively. However, leaf quality was crucial for a long (greater than 6 d) cocultivation. Several other experiments

showed that cocultivation with EHA105 more than $6 \mathrm{~d}$ caused severe damage to leaf tissues, resulting in no shoot regeneration. However, mature leaves ( 3 to 4 weeks old in vitro) showed tolerance to an extended cocultivation time and were easier to recover from the infection of Agrobacterium than young leaves ( 1 to 2 weeks old), allowing the plant cells to initiate regeneration more easily. Regenerated shoots from the selection medium were continuously subcultured three to four times in medium containing $\mathrm{CCK}_{40}$ and then maintained in antibiotic-free medium. No Agrobacterium was detected from grinded tissues of transgenic plants inoculated on the antibiotic-free culture medium, indicating that all bacteria had been killed by antibiotics (cefotaxime and carbenicillin) after three to four consecutive subcultures. Confirmed transgenic plants were grown in the greenhouse (Fig. 2B).

Histochemical $\beta$-glucuronidase assay. GUS staining showed blue in the leaves collected from both in vitro and greenhousegrown plants (Fig. 3), indicating that the uidA gene expressed in the leaf tissues. It was observed that blue staining can only be detected in in vitro young leaves for some lines. However, in a few other recovered lines, greenhouse-grown leaves showed much darker blue staining than in vitro leaves, showing a deferential expression of uidA gene under different conditions

Table 1. The effect of cocultivation time on shoot recovery from putative transformants of two Buddleia cultivars.

\begin{tabular}{|c|c|c|c|}
\hline \multirow{2}{*}{$\begin{array}{l}\text { Cocultivation time } \\
\text { (CCT) (days) }\end{array}$} & \multicolumn{3}{|c|}{ Shoot recovery rate $(\%)^{z}$} \\
\hline & Potters Purple & Lochinch & Avg. \\
\hline 3 & 6.1 & 5.3 & 5.7 \\
\hline 6 & 9.4 & 11.8 & 10.6 \\
\hline 9 & 31.7 & 32.3 & 32 \\
\hline $\begin{array}{l}\text { Least significant } \\
\text { difference }\end{array}$ & 7.0 & & \\
\hline $\mathrm{SOV}^{\mathrm{y}}$ & $\mathrm{df}$ & MS & $F$ \\
\hline CCT & 2 & $1,849.875$ & $7.93 * *$ \\
\hline Cultivar & 1 & 0.00056 & $0.00 \mathrm{NS}$ \\
\hline Cultivar $\times$ CCT & 2 & 12.9872 & $0.06 \mathrm{NS}$ \\
\hline
\end{tabular}

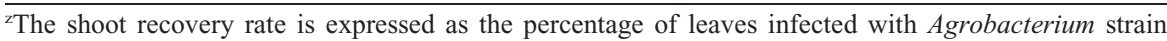
EHA105 forming shoots after 8 weeks (two subcultures) in vitro culture.

${ }^{\mathrm{y}} \mathrm{SOV}=$ source of variance; $\mathrm{MS}=$ mean square; $\mathrm{F}=\mathrm{F}$ value.

** Significant at $P \leq 0.01$.

NS $=$ nonsignificant.
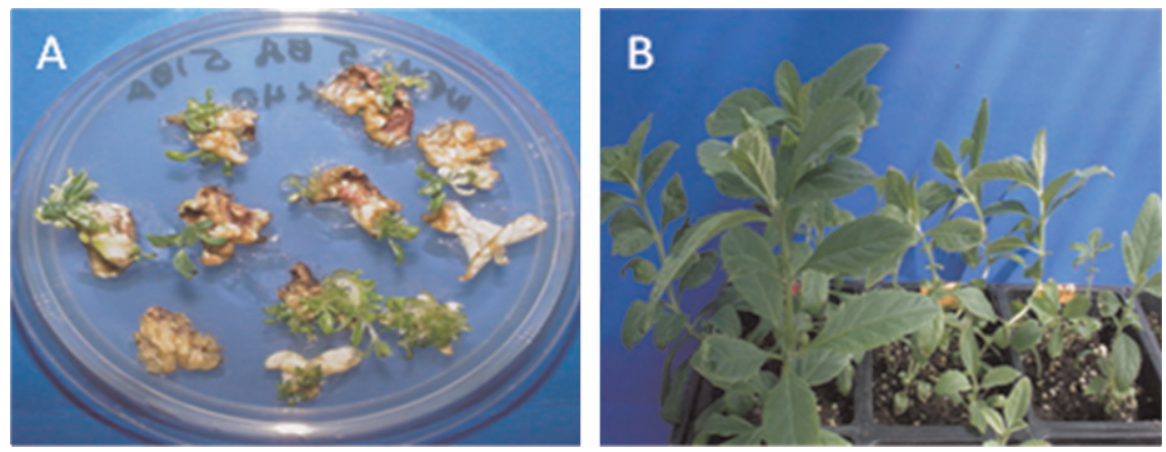

Fig. 2. (A) Shoots were regenerated from leaf explants infected with Agrobacterium EHA105 in woody plant medium containing $5 \mu \mathrm{M}$ 6-benzyladenine, $5 \mu \mathrm{M}$ naphthalene acetic acid, and $\mathrm{CCK}_{40}$. (B) Transgenic Buddleia plants were grown in the greenhouse. 
Polymerase chain reactions. GUS-positive regenerated lines were proliferated to have enough leaf tissues for genomic DNA extraction and subjected to PCR verification. The expected fragments of uidA (356 bp) and $n p t \mathrm{II}(410 \mathrm{bp})$ genes were successfully amplified from these plants using the specific primers (Fig. 4)

Southern blot analysis. Genomic DNA was digested with HindIII. Gel electrophoresis showed that DNA was well digested and separated. The digested DNA was hybridized with the ${ }^{32} \mathrm{P}$-labeled fragment of the nptII gene probe prepared from PCR product. The result showed that the transgenic lines exhibited one to three distinctive restriction fragments (Fig. 5), confirming that the nptII gene was integrated into the Buddleia genome.

In this study, genetic transformation of two Buddleia cultivars has been confirmed. Many factors such as genotype, Agrobacterium strain, conditions of infection, and cocultivation affect transformation frequency. The Buddleia cultivars used in this study are very amenable to plant regeneration from leaf tissues (Dai and Castillo, 2007). Thus, higher
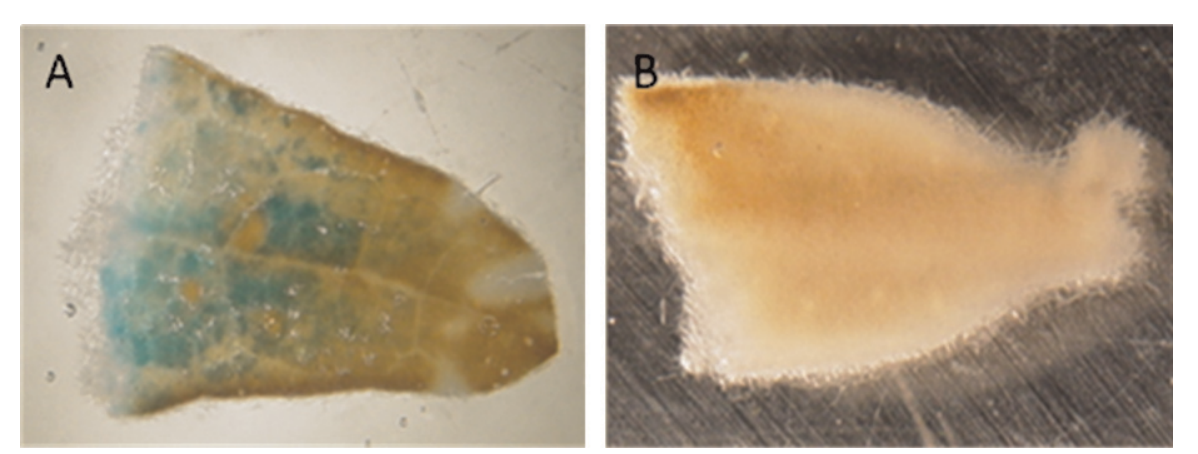

Fig. 3. $\beta$-glucuronidase staining of a leaf from transformed (A) and nontransformed (B) Buddleia plants. The blue color in $\mathbf{A}$ is the result of active beta-glucuronidase activity.

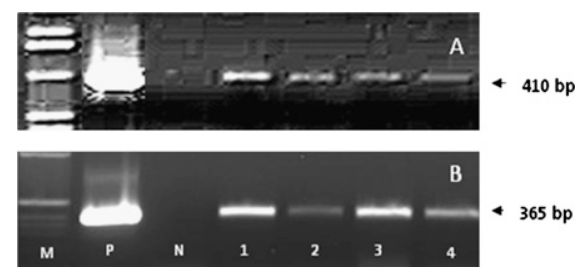

Fig. 4. Polymerase chain reaction amplification of $n p t I \mathrm{I}$ (A) and uidA (B) genes in transformed buddleia plants. Lanes $\mathrm{M}$ are DNA ladders. Lane $\mathrm{P}$ is positive control of plasmid pBI121. Lane $\mathrm{N}$ is negative control of untransformed buddleia. Lanes 1 to 4 are transformed lines.

transformation efficiency may be achieved if some improvements can be made during the Agrobacterium infection and transformant selection. For example, preconditioning explants, application of vacuum technique during the infection process, using different Agrobacterium strains, and extension of the cocultivation time may increase the T-DNA delivery efficiency. The large $F$ value of cocultivation time in this study indicated that the time of cocultivation was one of the most important factors attributing to a significant increase of shoot recovery from the selection medium, which is in agreement with other research (Cardoza and Stewart, 2003; Forreiter et al., 1997).

Many transgenic plants such as most monocot species have been initiated using embryogenic tissues from seedlings such as immature embryos, hypocotyls, and cotyledons. This limits application of gene transformation for improving vegetatively propagated species, especially for elite cultivar improvement, because of the trait segregation of seedpropagated plants. This is the first article reporting genetic transformation of Buddleia species, which was achieved by using leaf tissues from a mature plant. Therefore, this 